\title{
Energy Simulation of PV Hybrid System for Remote Villages of Thailand
}

\author{
Jitiwat Yaungket $^{1}$, Tetsuo Tezuka ${ }^{1}$, Boonyang Plangklang ${ }^{2}$ \\ ${ }^{1}$ Graduated School of Energy Science, Kyoto University, Kyoto, Japan \\ ${ }^{2}$ Faculty of Engineering, Rajamangala University of Technology, Thanyaburi, Thailand \\ Email: jitiwaty@gmail.com
}

Received May 1, 2013; revised June 1, 2013; accepted June 8, 2013

Copyright (c) 2013 Jitiwat Yaungket et al. This is an open access article distributed under the Creative Commons Attribution License, which permits unrestricted use, distribution, and reproduction in any medium, provided the original work is properly cited.

\begin{abstract}
A surveys conducted in remote rural areas revealed that some people still do not have access to electricity. Subsequently, the Ministry of Interior was assigned to invite relevant agency to a meeting designed to assist those without access to electricity the opportunity to enjoy electricity comprehensively in all households. This paper presents the design simulation of PV Hybrid System for remote village. The design uses real data from field investigated for different regions in Thailand. The obtained data was compiled as load profile. The analysis results will describe for the design for given energy generation from PV hybrid system. The energy to be generated from the back up diesel generator when the power generated from renewable energy technologies fails to meet the energy demand. This information can use as guideline for future developing energy system planning in the area without the sources of electricity.
\end{abstract}

Keywords: Energy Simulation; Hybrid System; Remote Village

\section{Introduction}

Thai government was aware of the importance and necessity for promotion of popular participation, the government viewpoint was that Thai people in all areas should have the opportunity to be informed of the news [1]. However, surveys conducted in remote rural areas revealed that some people still do not have access to electricity. Subsequently, the Ministry of Interior was assigned to invite relevant agency to a meeting designed to assist those without access to electricity the opportunity to enjoy electricity comprehensively in all households, at the least the opportunity to view television for news information even though the investment is not economically worthwhile. The reason was that it was considered government duty to provide support for public equality. The goal set was for all households to have access to electric power within the years 2005-2006. The principle was that homes located in areas where power cable poles can be installed, the Provincial Electricity Authority (PEA) was to expedite operations. Meanwhile, homes located in remote areas, in wooded, mountainous, island areas, etc. where power cable poles cannot be installed, Solar Home System (SHS) was to be installed instead. The SHS standard kit, which is provided free of cost to the rural households is composed of a PV module of $120 \mathrm{Wp}, 1$ control unit circuit with inverter, 2 fluorescent lamps and a $12 \mathrm{~V} / 125 \mathrm{Ah}$ battery, those locally produced. Private companies contracted by the Provincial Electricity Authority (PEA) are implementing the systems [2]. After systems installation has been carried out, maintenance work would be reassigned to local administration agencies at the sub-district (Tambon) level. In this way, we called Sub-district Administrative Organization (SAO). People will be given training and knowledge provided on systems usage and maintenance, etc. Accordingly, the SAO will be responsible for laying down administrative rules for further sustained operations in accordance with concerned projects. Target areas of the project are households still without access to electricity and located in remote areas where the PEA cannot provide service numbering around 290,716 households. The source of the operational budget is Local Administration Agency subsidy funds for Fiscal Years B.E. 2547 and 2548 (A.D. 2004-2005) totaling 7,631,295,000 baht ${ }^{1}$ [3], which translates to an installation expense per household of 25,000 baht [1]. Power supplied by solar home system SHS is 120 Watts with Alternating Currency (AC) power used with two 10-Watt fluorescent lamps and one 14-inch television set. The project has

${ }^{1} 30$ Baht $=1$ USD. 
finalized operations at the end of 2006.

Energy community in remote villages of Thailand found themselve being equipped with solar PV systems provided by the government of Thailand as we mentioned above and diesel generators donated by the organizations in Thailand or agriculture diesel generator uses to generate electricity for support recovery efforts. However the electricity generating capacity the villagers could only benefit from an electricity supply for a few hours each day and besides this, important parts of the equipment failed. In addition, the conclusions of this study suggest that by using the existing workable components as a base, the creation of a hybrid energy system using diesel and renewable energy sources could provide a sustainable 24 hour-electricity supply for the villages. This is to be accomplished by showing data on real time system usage situations, simulation and guidelines on development of PV hybrid system to be the optimum electric power generation system. Supporting information comprise information directly from system survey questionnaires and interview with villagers was derived for four different regions in Thailand as follows are; Bann Bon Khao Kang Riang Village, Kanchanaburi Province (Western Thailand), Bann Koh Jik Island Chantaburi Province (Eastern Thailand), Bann Pa Ya Sai Village, Chiang Mai Province (Northern Thailand) and Bann Klong Rua Village, Chumporn Province(Southern Thailand) and secondary information from various agencies concerned [4]. The foremost hindrance to quality of life development on the study areas is the lack of national grid connected. It is unlikely that a grid extension could be possible in the near future as the current electricity demand on the study areas is low and not economically viable for Thailand's public utility, the Provincial Electricity Authority (PEA), to invest in the expensive underwater cable to connect the Island with the mainland's grid system also in the mountainous areas. The planned hybrid system discussed in this study presents the possibility of expanding electricity supplies in ways that are controlled by the community itself.

\section{Energy Demand Assessment}

As mentioned, the principle design of this mobile PV hybrid system will be considered at the stability of power supply. The real time monitoring system is also included for data analysis. For this study, we selected an example of load profile as shown in Figure 1. The selected load profile is a typical load in remote areas which has the peak load in the evening. The load normally includes the daily life electrical load without air conditioning system.

After having the load profile, the capacity of the solar cell, $P_{\text {peak }}$, can be calculated by using a method [5] as followings.

$$
\begin{aligned}
& Q=E_{\text {el }} / E_{\text {th }} \\
& E_{\text {th }}=n \text { Efficiency } \times I_{\text {glob }} \times A P V_{\text {array }} \\
& P_{\text {peak }}=n \text { Efficiency } \times I_{S} \times A P V_{\text {array }} \\
& E_{\text {th }}=P_{\text {peak }} \times\left(I_{\text {glob }} / I_{S}\right) \\
& Q=\left(E_{\text {el }} /\left(I_{\text {glob }} / P_{\text {peak }}\right)\right) \times I_{S} \\
& P_{\text {peak }}=\left(E_{\text {el }} \times I_{S}\right) /\left(I_{\text {glob }} \times Q\right)
\end{aligned}
$$

when: $P_{\text {peak }}=$ peak power of the PV array under STC [kWp].

$E_{e l}=$ real electric output energy of the system [kWh/a].

$I_{S}=$ incident solar radiation under $S\left[1 \mathrm{~kW} / \mathrm{m}^{2}\right]$.

$I_{\text {glob }}=$ annual global solar radiation $\left[\mathrm{kWh} / \mathrm{m}^{2} \mathrm{a}\right]$.

$Q=$ quality factor of the system.

$E_{t h}=$ theoretical output energy of the system [kWh/a].

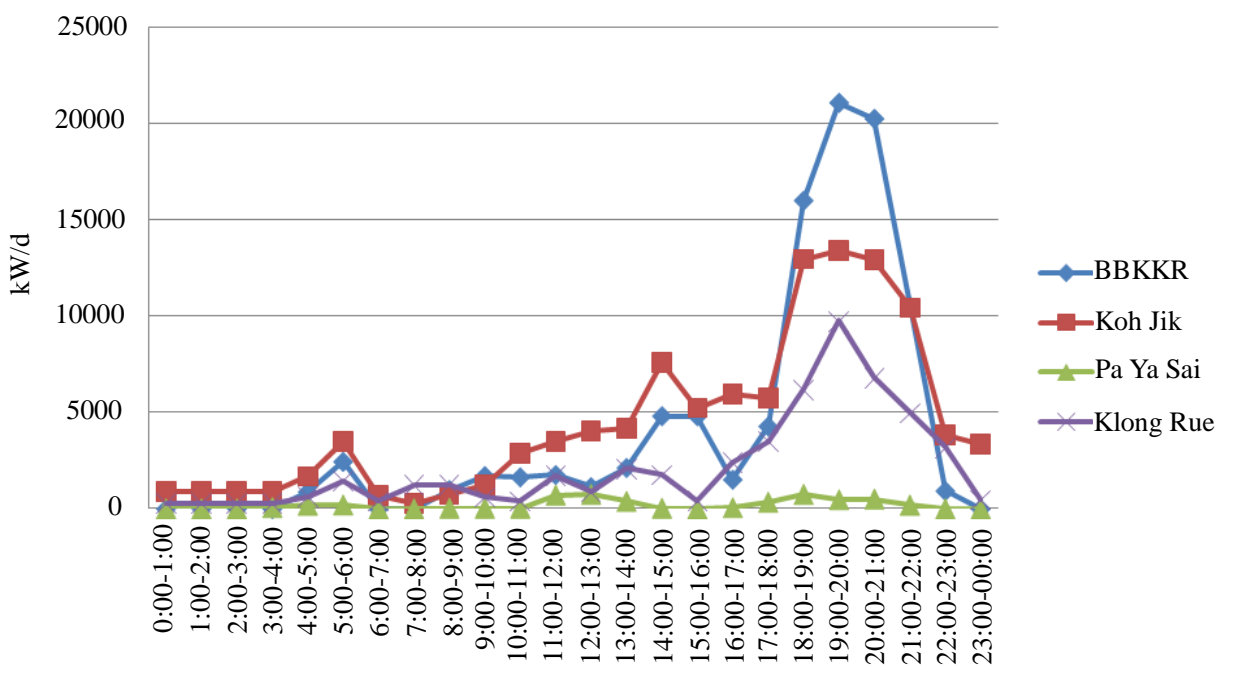

Figure 1. Daily load profile of areas study for system design. 
$n$ Efficiency = efficiency of the PV array [decimal]. $A P V_{\text {array }}=$ area of the $\mathrm{PV}$ array $\left[\mathrm{m}^{2}\right]$.

The battery capacity is calculated by (7).

$$
C B=10 \times P_{\text {peak }}
$$

when: $P_{\text {peak }}=$ peak power of the PV array under STC [kWp].

$C B=$ battery capacity $[\mathrm{kWh}]$.

Therefore the calculation can be done as following by having the $E_{\text {glob }}\left(\mathrm{kWh} / \mathrm{m}^{2}\right)$ in Thailand and the load from the load profile $(\mathrm{kWh} / \mathrm{d})$ as shown the results in Table 1.

\section{System Design and Selection of Operation System}

The systems have 3 main operation modes. In the first mode where solar energy is sufficient for generate electricity and supply to the load directly, the excess energy will be charged into the battery, when the solar energy shortage battery will be discharge to supply the load. In the second mode where the solar and battery energy not sufficient the system will be switch to use the energy from the grid line until the energy level of solar and battery is possible to supply the load it will be switch back.

In the third mode where the energy from the system is into grid line by the grid connected inverter in case of battery full and no load demand.

The selection of operation system consists of system voltage and system operation.

- System voltage: for small hybrid system voltage should be 12 - $48 \mathrm{~V}$, for medium size should be 120 $240 \mathrm{~V}$, and a big size is $480-600 \mathrm{~V}$. Hence, the level of battery voltage can be selected depending on the level of load consumption [6]. For the hybrid system of Bann Pa Ya Sai is a very small size, there, the system voltage is 24 volts has selected. Therefore three villages larger than Bann Pa Ya Sai voltage level selected the voltage of battery 96 volts.

- The simulations for hybrid system of four villages are as shown in Figures 2-5.

Estimation of electricity generating system HOMER tool uses for estimate the electricity generating system. The capacity of the components of the hybrid system simulation in this paper is shown in Table 2.

Table 1. The calculation results of the capacity of PV and battery capacity.

\begin{tabular}{ccc}
\hline Village & Peak power $[\mathrm{kWp}]$ & battery capacity $[\mathrm{kWh}]$ \\
\hline BBKKR & 30.3 & 303 \\
Koh Jik & 35 & 350 \\
Pa Ya Sai & 1.4 & 14 \\
Klong Rue & 16.3 & 163 \\
\hline
\end{tabular}

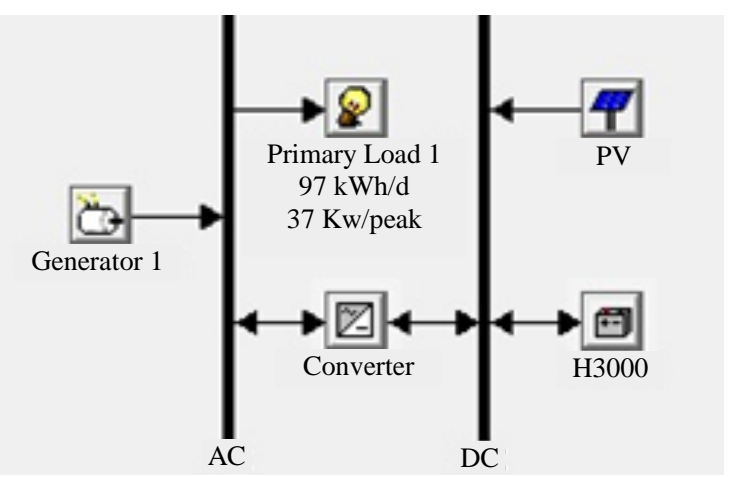

Figure 2. Simulation of BBKKR hybrid system.

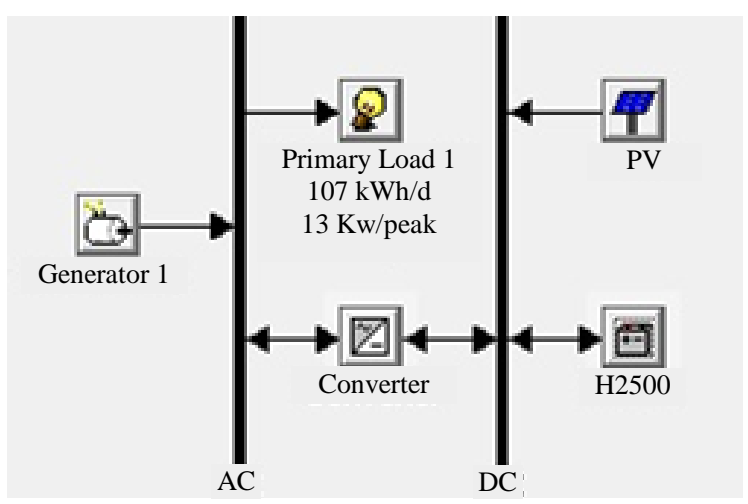

Figure 3. Simulation of Koh Jik hybrid system.

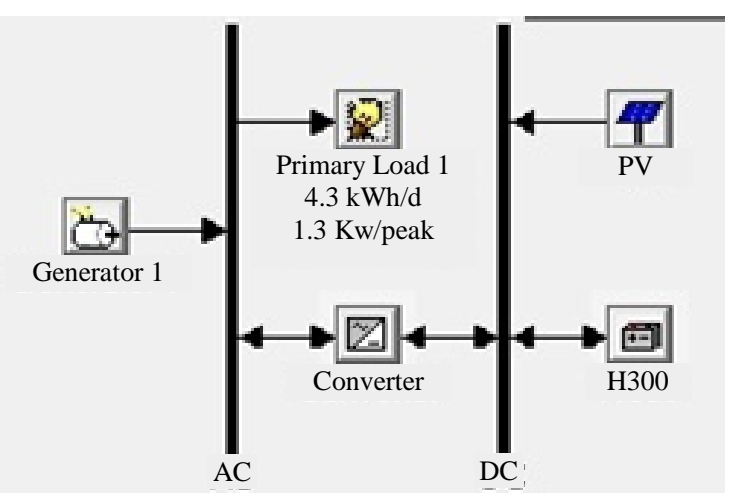

Figure 4. Simulation of Pa Ya Sai hybrid system.

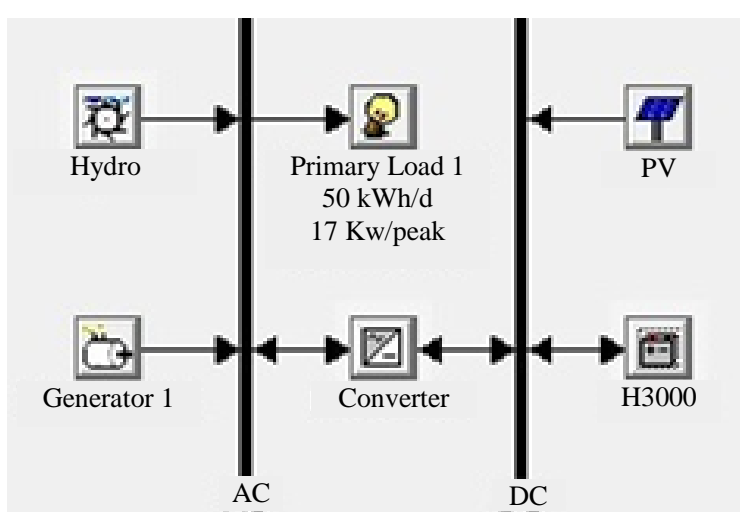

Figure 5. Simulation of Klong Rue hybrid system. 


\section{Results}

The PV hybrid system simulated in the present investigation considered at the stability of power supply for different regions in Thailand. In order to show the ultimately PV hybrid power, the monthly average electric production for 4 villages is presented in Figures 6-10. The figures show distinctly of the different of energy sources to generate electricity. The Solar PV system is the single largest unit to supply the electricity in the north, west, east of Thailand whereas the south region of
Table 2. The capacity of the components.

\begin{tabular}{ccccc}
\hline Village & $\begin{array}{c}\text { PV } \\
{[\mathrm{kWp}]}\end{array}$ & $\begin{array}{c}\text { battery capacity } \\
{[\mathrm{kWh}]}\end{array}$ & $\begin{array}{c}\text { Diesel Gen. } \\
{[\mathrm{kW}]}\end{array}$ & $\begin{array}{c}\text { Hydro power } \\
{[\mathrm{kW}]}\end{array}$ \\
\hline BBKKR & 25 & 303 & 15 & - \\
Koh Jik & 20 & 350 & 15 & - \\
Pa Ya Sai & 1 & 15 & 2 & - \\
Klong Rue_1 & 4 & 163 & 10 & 100 \\
Klong Rue_2 & 7 & 163 & 20 & w/o HP \\
\hline
\end{tabular}

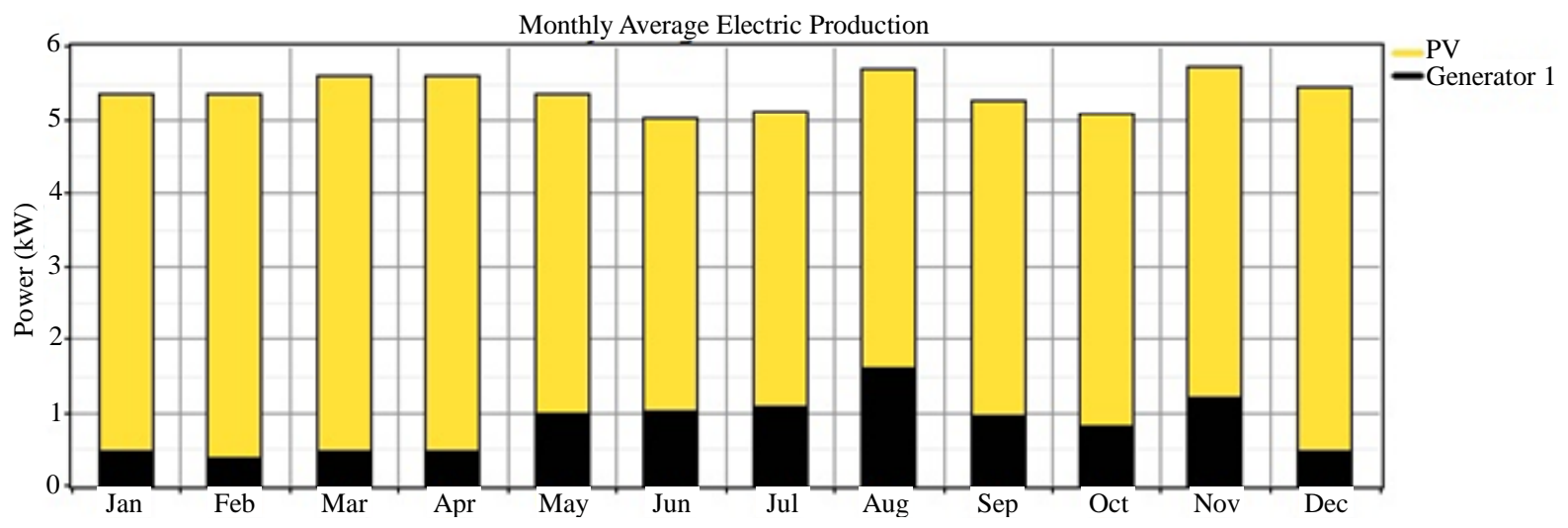

Figure 6. Monthly average electric production in BBKKR village.

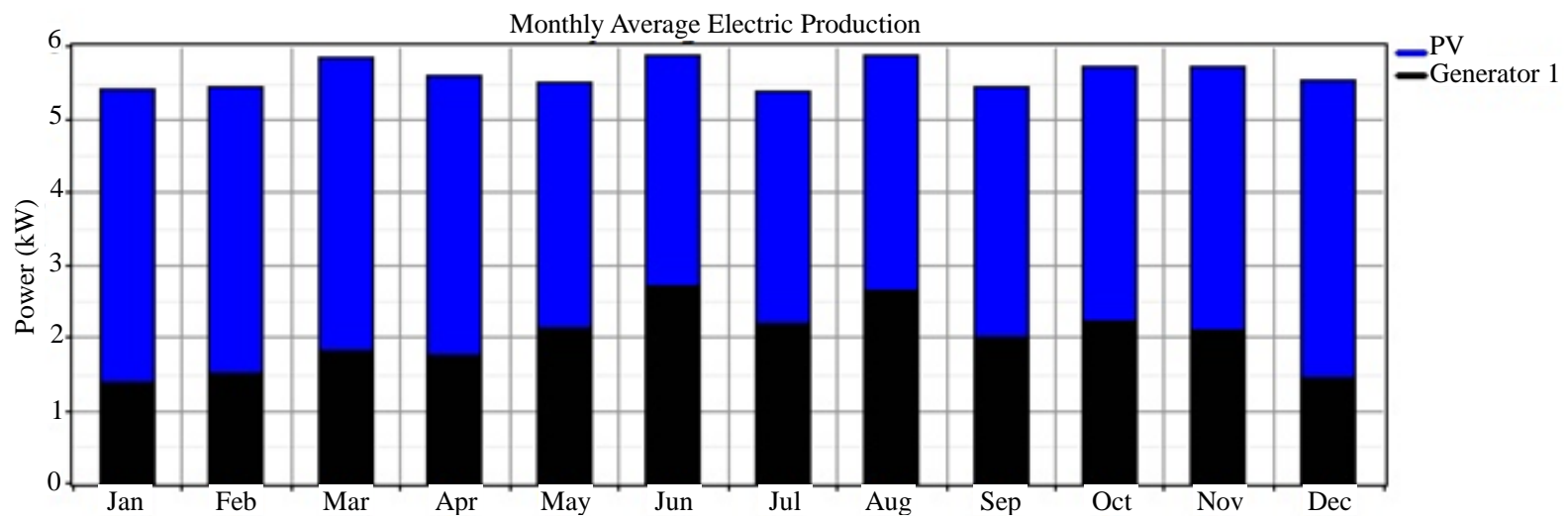

Figure 7. Monthly average electric production in Koh Jik village.

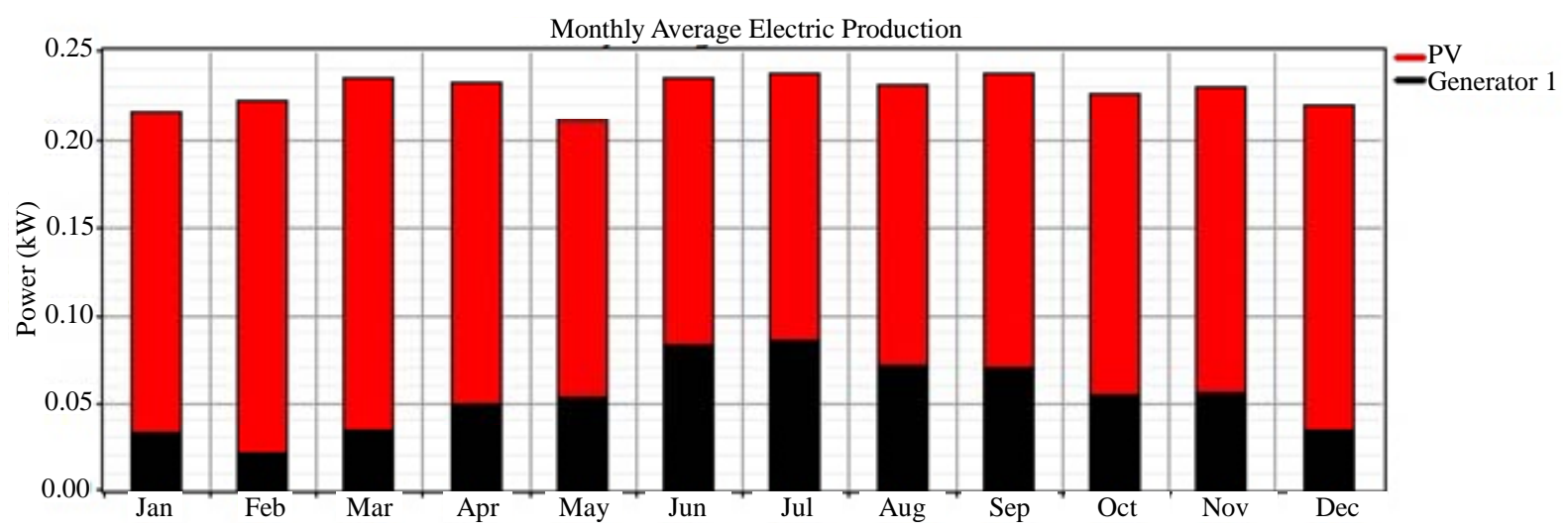

Figure 8. Monthly average electric production in Pa Ya Sai village. 


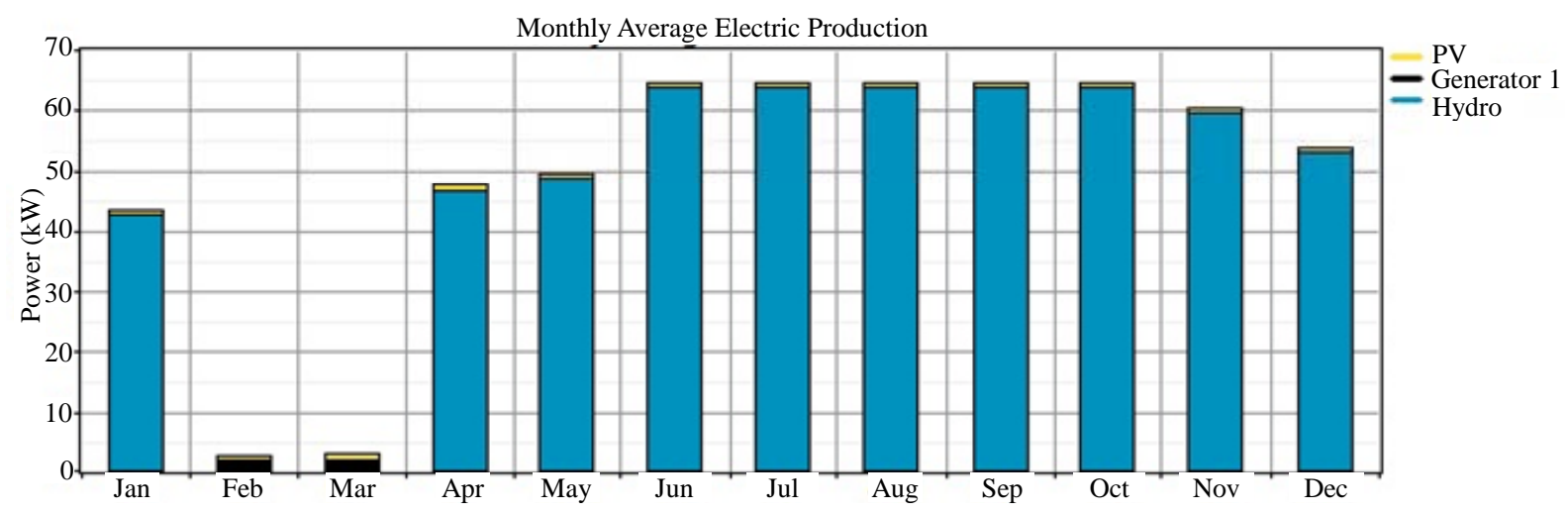

Figure 9. Monthly average electric production in Klong Rue village with hydro power.

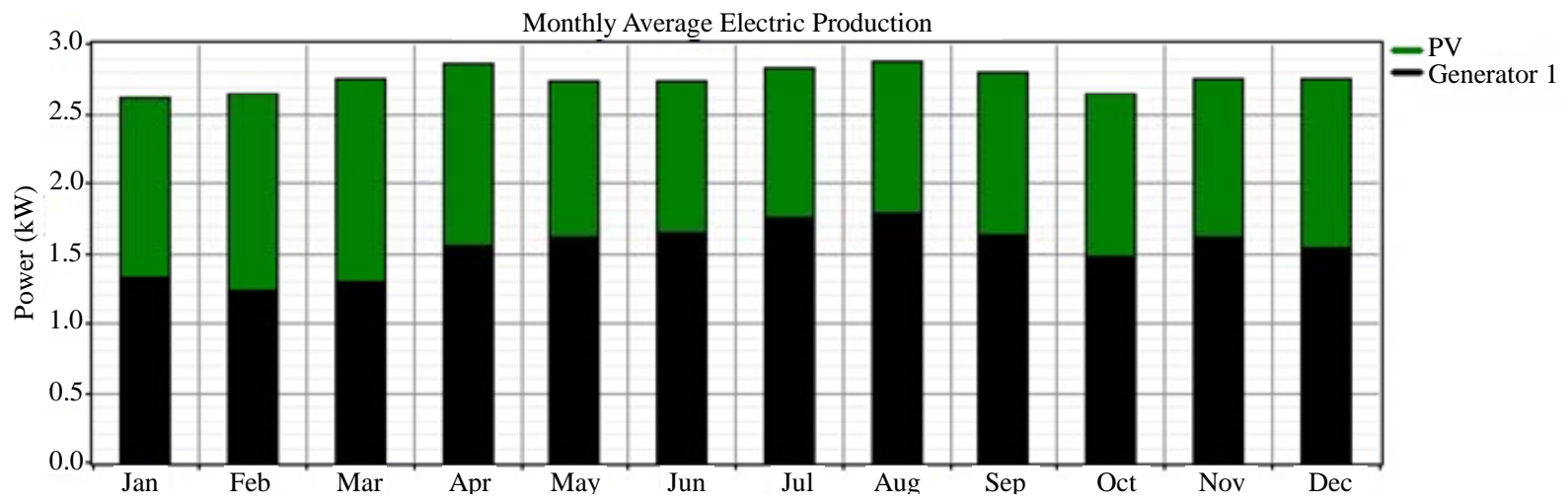

Figure 10. Monthly average electric production in Klong Rue village without hydro power.

Thailand, we found that the solar PV system was not able to fully satisfy their electric power supply needs. What this means is that the geographical location of Klong Rua village is situated in a regional with a rainy season 8 months per annum. Thus, it has been given the nickname: "Eight Months Rainy and Four Months Sunshine" province, where the solar PV system is unable to generate electricity while it is raining. Thus, diesel generator is the major share of the hybrid system in the south region of Thailand. It is due to these reasons that potency in southern areas regarding water is an alternative choice for electric power for this region with endless uses.

The figures below showed the results of the study areas from HOMER modeling. The results of simulation show that the designed system can supply power stably without energy shortage shown in Figures 10-15.

\section{Discussions}

\subsection{Evaluation of the System on Remote Village: Sustainability and Social Impact}

The most significant issues regarding the sustainability of the existing electricity arrangements are 1) ongoing technical sustainability of the system; 2) fuel expenses. From the Figures 6-10 above we can say that so far the diesel generators have worked well, but there is limited local knowledge on operation and maintenance (O\&M) and villagers are concerned that if the generators break down sometimes they do not know who to contact. In addition, PV systems are getting to fail in highly numbers of the systems, and failure rates will likely increase substantially in the rainy season (during summer and winter) because lower light levels will lead to a power deficit.

Environmental impacts from the diesel engine to generate electric power include noise. We mentioned as noise as an impact to concern in the Koh Jik village and the diesel engine appear closely from residential houses.

Environmental impact from the PV system is a little small thing. The largest concern is the recycling of the lead-acid batteries. The villagers report that they already sold non-functional batteries several times in few years to a materials recycle that comes to the village.

\subsection{The Proposed Future Hybrid System as Follows}

- To provide the electricity power quality available to remote villagers, for instance; 24 hrs power, use of refrigerators, rice cooker, and so on electric appliances throughout the useful lifetime system operations. 


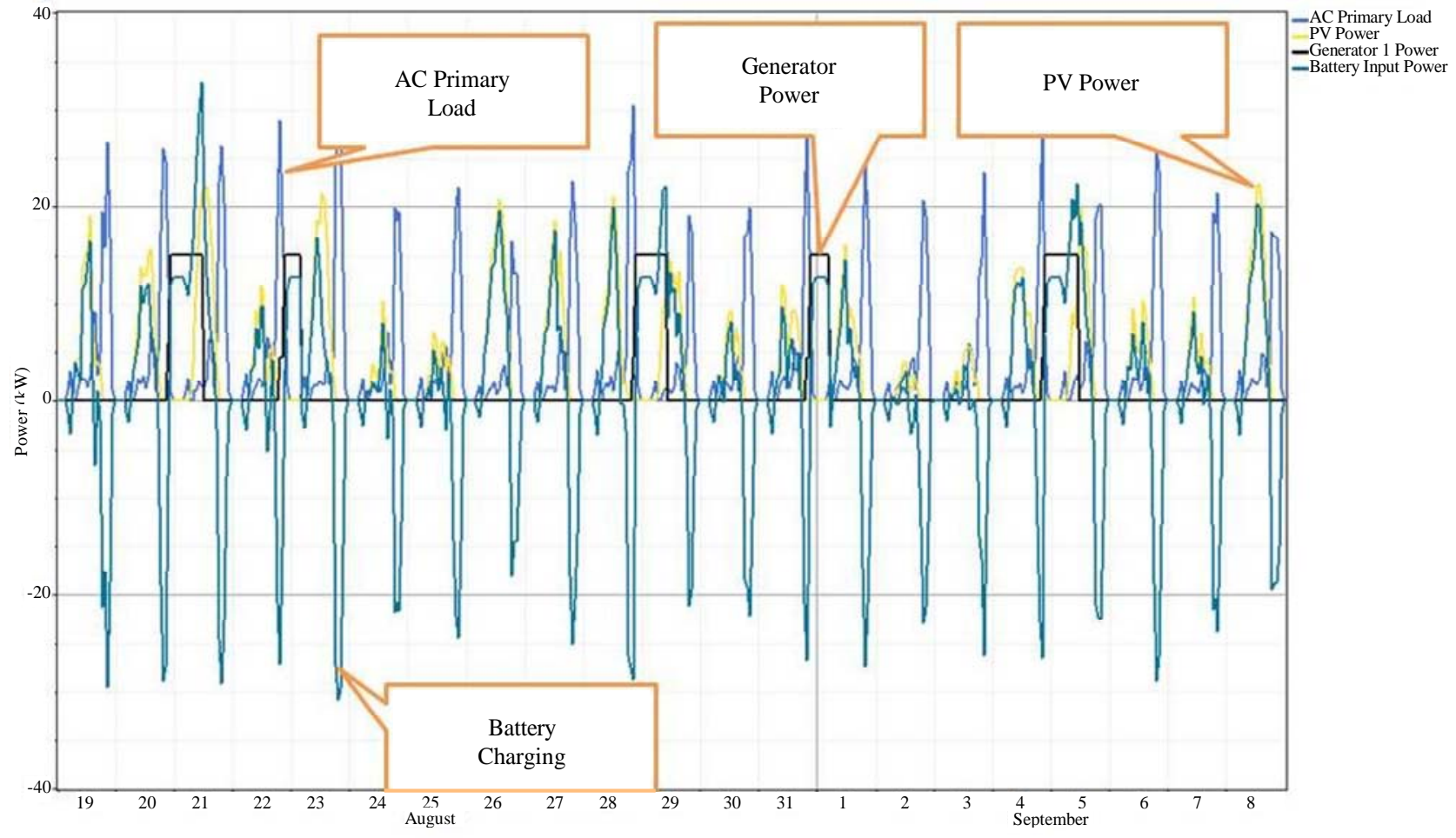

Figure 11. BBKKR simulation results.

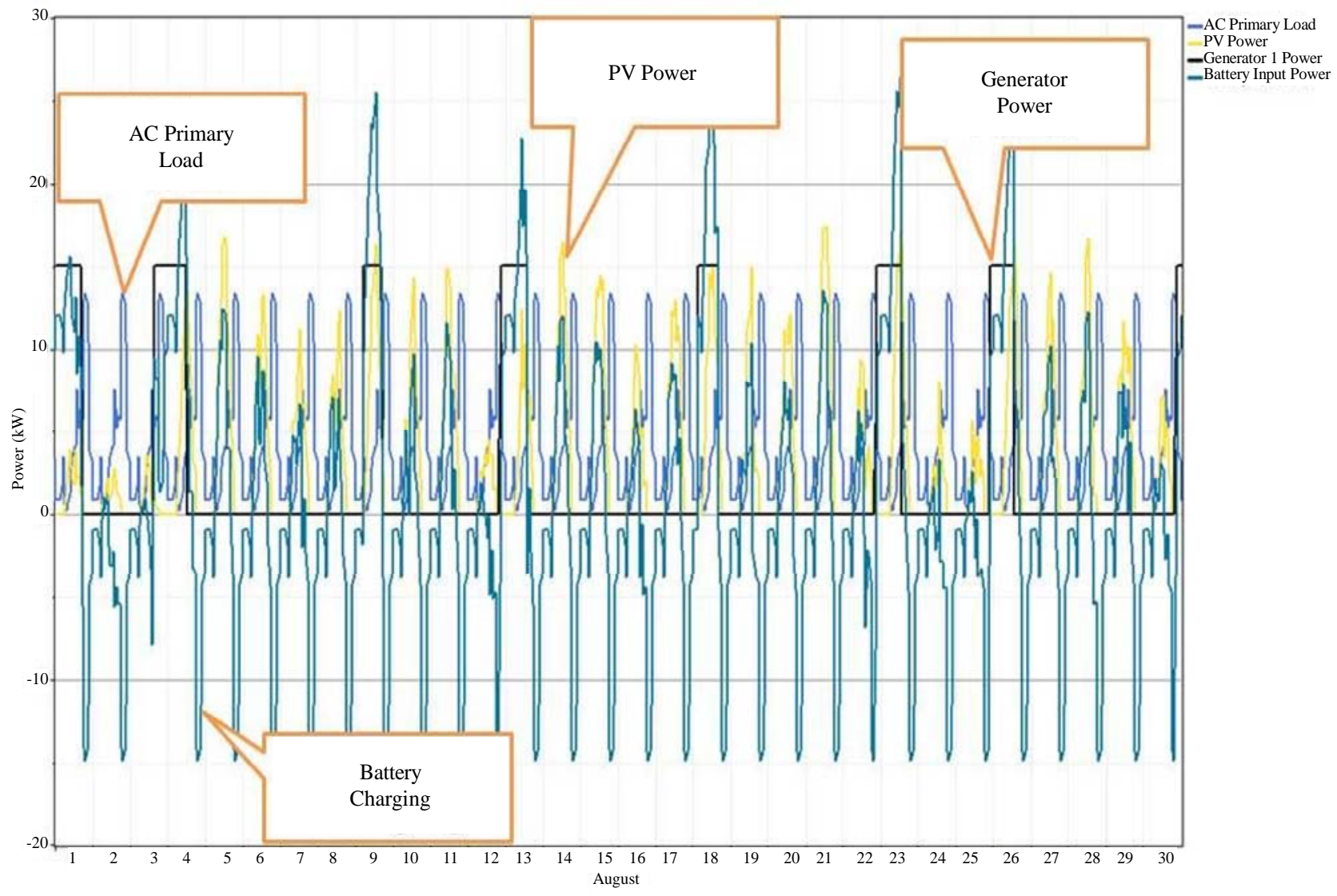

Figure 12. Koh Jik simulation results. 


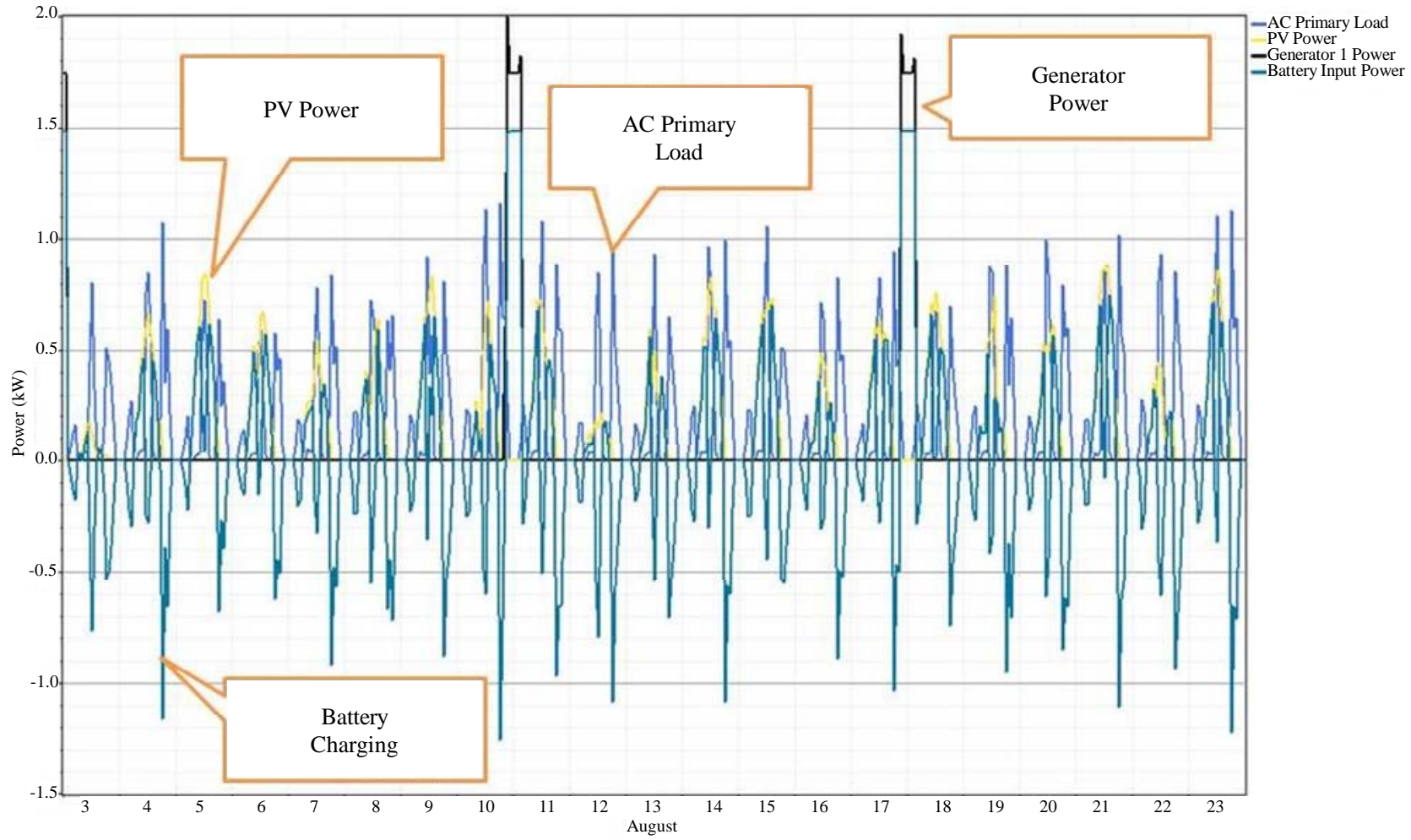

Figure 13. Bann Pa Ya Sai simulation result.

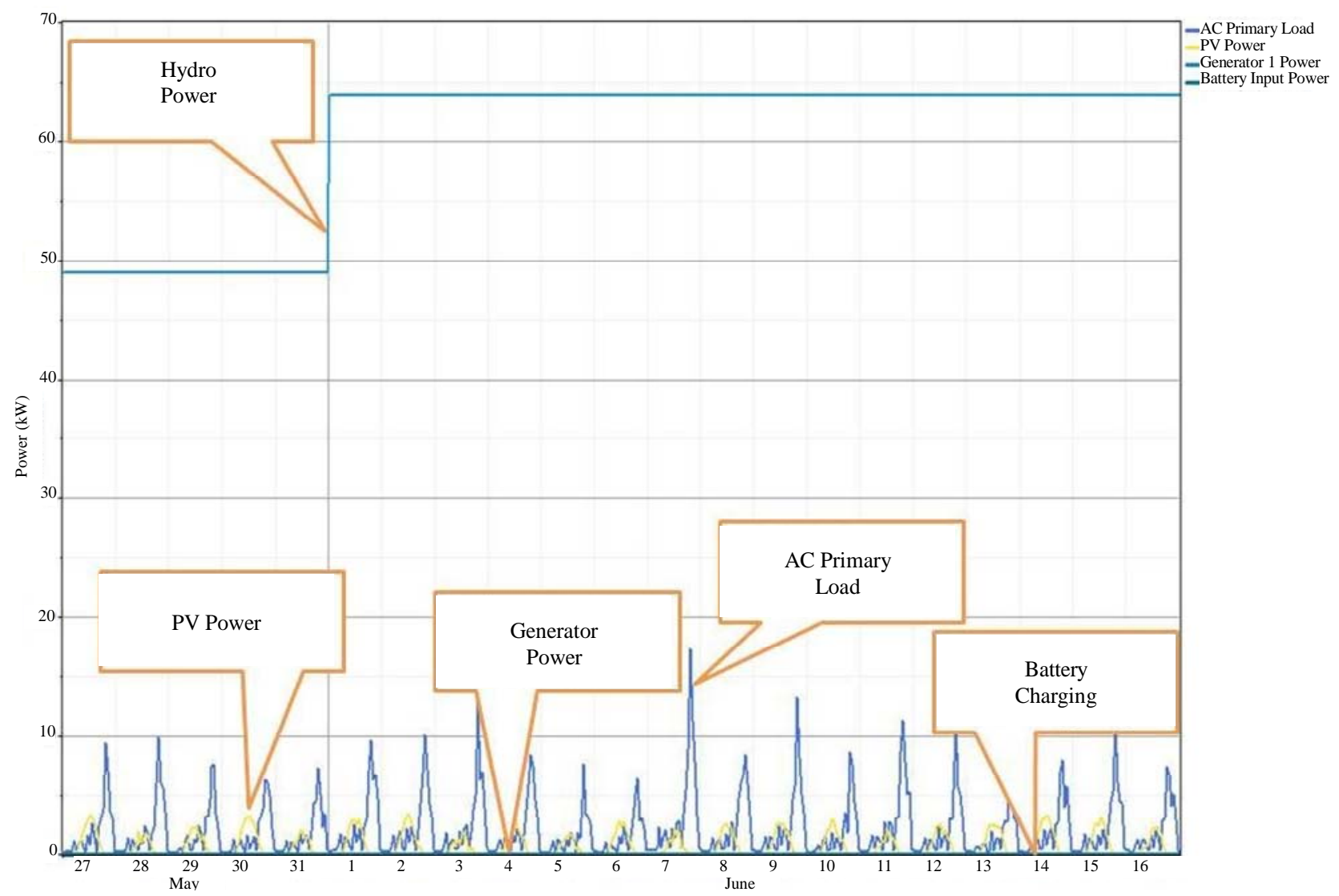

Figure 14. Bann Klong Rue simulation result with hydro power. 


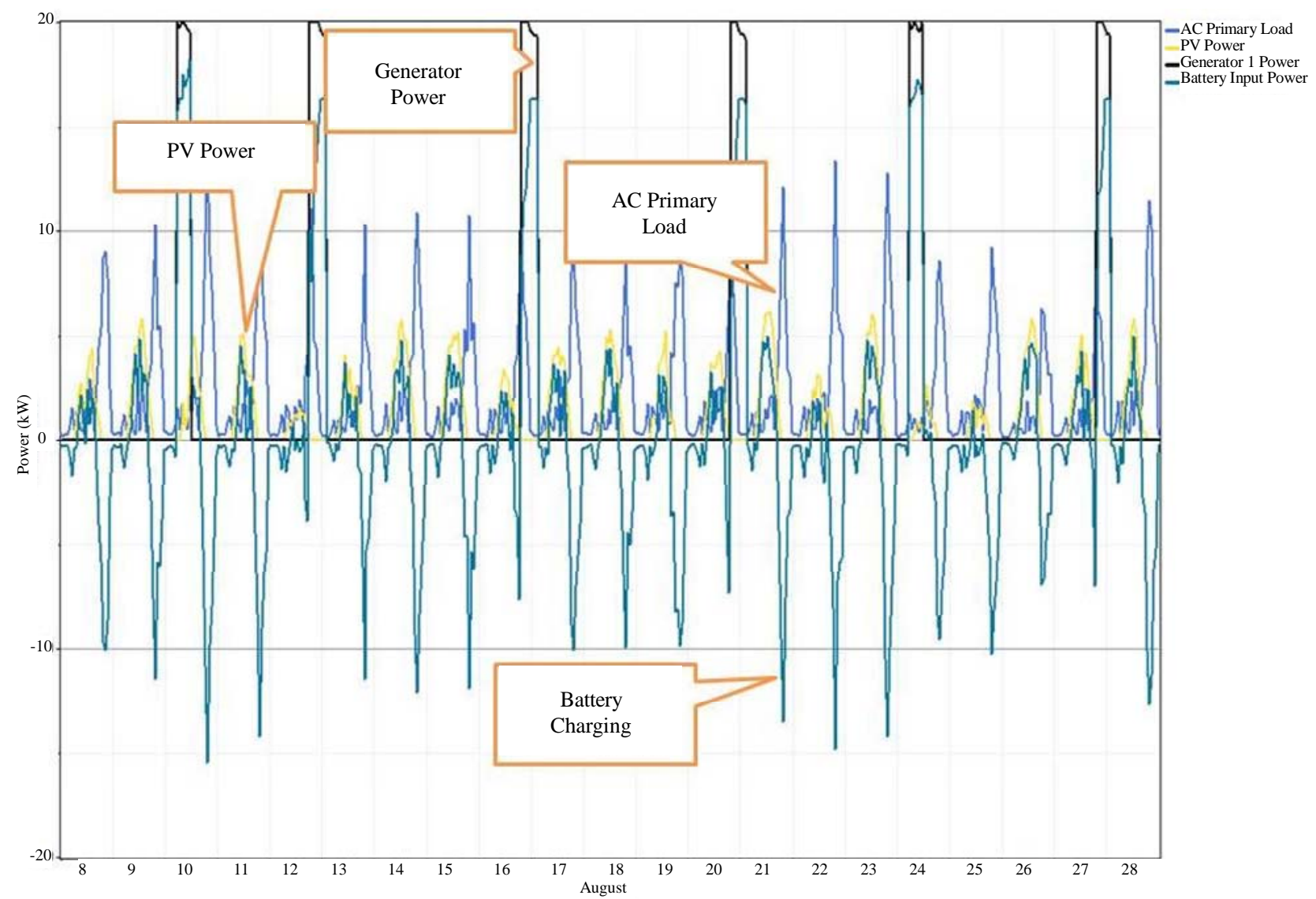

Figure 15. Bann Klong Rue simulation result without hydro power.

- To design in which renewable energy sources or combination of sources as hybrid renewable energy system for serving as a structured opportunity to build local technical.

- To gives the lowest costs to villagers through a more efficient use of the power generator.

\section{Conclusion}

The paper presents a method of design for PV hybrid system. The system design after the calculation is simulated by Homer program for system optimization. HOMER modeling results indicate that remote village electricity needs could be met at considerable available of resources with a hybrid (renewable energy/diesel) system compared with existing arrangements (separate diesel generator plus solar PV system).

\section{REFERENCES}

[1] Provincial Electricity Authority (PEA), "Solar Home
System Project,” 2005.

http://www.pea.co.th/project/project_solar.htm

[2] R. Shrestha, S. Kumar, S. Martin and N. Limjeerajarus, "Role of Renewable Energy for Productive Uses in Rural Thailand," Global Network on Energy for Sustainable Development (GNESD), New York, 2006.

[3] P. Kruanpradit, S. Saengsrithorn and S. Sriphirom, "Electricity Supply by Solar Home System in Thailand," Proceedings of 14th Technical Digest of the International PVSEC, Bangkok, 2004, pp. 781-783.

[4] J. Yaungket and T. Tezuka, “A Survey of Remote Household Energy Use in Rural Thailand,” Energy ProcediaScience Direct, 2013.

[5] B. Plangklang, "Photovoltaic Systems," 1st Edition, Triple Education Co., Ltd., Bangkok, 2011.

[6] B. Plangklang, R. Skunpong, K. Phumkittphich and S. Hiranvarodom, "Analysis of Energy Consumption and Behavior of Television in Resident Houses in Thailand," The 2nd International Science, Social Science, Engineering and Energy Conference, 2010 Procedia Engineering-Science Direct, 2011, pp. 115-119. 